\title{
Front Matter: Volume 8382
}

, "Front Matter: Volume 8382," Proc. SPIE 8382, Active and Passive Signatures III, 838201 (7 June 2012); doi: 10.1117/12.979461

Event: SPIE Defense, Security, and Sensing, 2012, Baltimore, Maryland, SPIE. United States 


\title{
PROCEEDINGS OF SPIE
}

\section{Active and Passive Signatures III}

\author{
G. Charmaine Gilbreath \\ Chadwick T. Hawley \\ Editors
}

25-26 April 2012

Baltimore, Maryland, United States

Sponsored and Published by

SPIE

Volume 8382 
The papers included in this volume were part of the technical conference cited on the cover and title page. Papers were selected and subject to review by the editors and conference program committee. Some conference presentations may not be available for publication. The papers published in these proceedings reflect the work and thoughts of the authors and are published herein as submitted. The publisher is not responsible for the validity of the information or for any outcomes resulting from reliance thereon.

Please use the following format to cite material from this book:

Author(s), "Title of Paper," in Active and Passive Signatures III, edited by G. Charmaine Gilbreath, Chadwick T. Hawley, Proceedings of SPIE Vol. 8382 (SPIE, Bellingham, WA, 2012) Article CID Number.

ISSN 0277-786X

ISBN 9780819490605

Published by

SPIE

P.O. Box 10, Bellingham, Washington 98227-0010 USA

Telephone +1 3606763290 (Pacific Time) · Fax +1 3606471445

SPIE.org

Copyright () 2012, Society of Photo-Optical Instrumentation Engineers

Copying of material in this book for internal or personal use, or for the internal or personal use of specific clients, beyond the fair use provisions granted by the U.S. Copyright Law is authorized by SPIE subject to payment of copying fees. The Transactional Reporting Service base fee for this volume is $\$ 18.00$ per article (or portion thereof), which should be paid directly to the Copyright Clearance Center (CCC), 222 Rosewood Drive, Danvers, MA 01923. Payment may also be made electronically through CCC Online at copyright.com. Other copying for republication, resale, advertising or promotion, or any form of systematic or multiple reproduction of any material in this book is prohibited except with permission in writing from the publisher. The CCC fee code is 0277-786X/12/\$18.00.

Printed in the United States of America.

Publication of record for individual papers is online in the SPIE Digital Library.

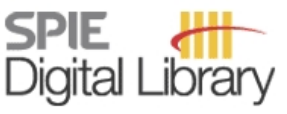

SPIEDigitalLibrary.org

Paper Numbering: Proceedings of SPIE follow an e-First publication model, with papers published first online and then in print and on CD-ROM. Papers are published as they are submitted and meet publication criteria. A unique, consistent, permanent citation identifier (CID) number is assigned to each article at the time of the first publication. Utilization of CIDs allows articles to be fully citable as soon as they are published online, and connects the same identifier to all online, print, and electronic versions of the publication. SPIE uses a six-digit CID article numbering system in which:

- The first four digits correspond to the SPIE volume number.

- The last two digits indicate publication order within the volume using a Base 36 numbering system employing both numerals and letters. These two-number sets start with 00, 01, 02, 03, 04 , $05,06,07,08,09,0 A, 0 B \ldots$. OZ, followed by 10-1Z, 20-2Z, etc.

The CID number appears on each page of the manuscript. The complete citation is used on the first page, and an abbreviated version on subsequent pages. Numbers in the index correspond to the last two digits of the six-digit CID number. 


\section{Contents}

vii Conference Committee

\section{SESSION 1 ACTIVE AND PASSIVE SIGNATURES III}

838202 Disaster relief through composite signatures (Invited Paper) [8382-01]

C. T. Hawley, Signatures Support Program (United States); B. Hyde, T. Carpenter, ASR, Inc.

(United States); S. Nichols, Technigraphics Inc. (United States)

838203 The U.S. Army Research Laboratory (ARL) multimodal signature database (MMSDB) advanced data storage solutions and security of data over the web [8382-02] K. Bennett, U.S. Army Research Lab. (United States); J. Robertson, Clearhaven Technologies LLC (United States)

838204 An interactive 2-D power-line modeling and simulation tool [8382-03]

D. Hull, R. Adelman, U.S. Army Research Lab. (United States)

\section{SESSION 2 MATERIALS DETECTION SIGNATURES}

838206 Enhancing nuclear quadrupole resonance (NQR) signature detection leveraging interference suppression algorithms [8382-06]

J. A. DeBardelaben, J. K. Miller, W. Myrick, IvySys Technologies, LLC (United States);

J. B. Miller, G. C. Gilbreath, B. Bajramaj, U.S. Naval Research Lab. (United States)

838207 Entangled-photons Raman spectroscopy [8382-30]

M. Lanzagorta, U.S. Naval Research Lab. (United States)

838209 Neutron detection based on capture-gamma sensing and calorimetry [8382-08] G. Pausch, C.-M. Herbach, FLIR Radiation GmbH (United States); D. Mitchell, Sandia National Labs. (United States); R. Lentering, J. Stein, FLIR Radiation GmbH (United States)

8382 OA Photofission signatures for the detection of highly enriched uranium (Invited Paper) [8382-09]

S. A. Pozzi, S. D. Clarke, Univ. of Michigan (United States)

8382 OB Detection and identification of compound explosive using the SDA method of the reflected THz signal (Invited Paper) [8382-10]

V. A. Trofimov, S. A. Varentsova, Lomonosov Moscow State Univ. (Russian Federation);

M. Szustakowski, N. Palka, Military Univ. of Technology (Poland)

8382 OC Resonance structure of water complexes of B-HMX for THz frequencies [8382-11] L. Huang, U.S. Naval Research Lab. (United States); A. Shabaev, George Mason Univ. (United States); S. G. Lambrakos, N. Bernstein, V. Jacobs, U.S. Naval Research Lab. (United States);

L. Massa, Hunter College, CUNY (United States) 
8382 OD Data dependency on measurement uncertainties in speaker recognition evaluation [8382-12]

J. C. Wu, A. F. Martin, C. S. Greenberg, R. N. Kacker, National Institute of Standards and Technology (United States)

8382 OE Speckle signatures of articulating humans [8382-13]

D. G. Conrad III, Univ. of Dayton (United States); E. A. Watson, Air Force Research Lab. (United States)

$8382 \mathrm{OF}$ The use of spectral skin reflectivity and laser doppler vibrometry data to determine the optimal site and wavelength to collect human vital sign signatures [8382-14]

K. A. Byrd, B. Kaur, V. A. Hodgkin, U.S. Army Night Vision \& Electronic Sensors Directorate (United States)

\section{SESSION 4 SPECTRAL SIGNATURES}

$83820 \mathrm{~J} \quad$ Study of hyperspectral characteristics of different types of flares and smoke candles [8382-19]

V. Farley, M. Chamberland, P. Lagueux, Telops Inc. (Canada); M. Kastek, T. Piatkowski,

R. Dulski, Military Univ. of Technology (Poland)

8382 OK Multispectral and hyperspectral measurements of soldier's camouflage equipment [8382-20]

M. Kastek, T. Piątkowski, R. Dulski, Military Univ. of Technology (Poland); M. Chamberland, P. Lagueux, V. Farley, Telops Inc. (Canada)

$8382 \mathrm{OL} \quad$ Blind separation of human- and horse-footstep signatures using independent component analysis [8382-21]

A. Mehmood, T. Damarla, U.S. Army Research Lab. (United States)

$83820 \mathrm{M} \quad$ Analysis of electrostatic charge on small-arms projectiles [8382-22]

S. Vinci, J. Zhu, D. Hull, U.S. Army Research Lab. (United States)

\section{SESSION 5 MATHEMATICAL METHODS}

838200 Tripod operators for efficient search of point cloud data for known surface shapes (Invited Paper) [8382-24]

F. Pipitone, C. Gilbreath, D. Bonanno, U.S. Naval Research Lab. (United States)

8382 OP Acoustic change detection algorithm using an FM radio [8382-25]

G. H. Goldman, O. Wolfe, U.S. Army Research Lab. (United States)

\section{SESSION 6 ATMOSPHERIC AND TROPOSPHERIC SIGNATURES}

$8382 \mathrm{OQ}$ Characterization of the atmosphere as a random bit-stream generator [8382-26]

C. Font, D. Bonanno, H. Long, B. Bajramaj, G. C. Gilbreath, U.S. Naval Research Lab. (United States) 
8382 OR Coherent uplink arraying techniques for next generation orbital debris, near earth object, and space situational awareness radar systems (Invited Paper) [8382-27]

B. J. Geldzahler, NASA Headquarters (United States)

Author Index

Proc. of SPIE Vol. $8382838201-5$

Downloaded From: https://www.spiedigitallibrary.org/conference-proceedings-of-spie on 26 Apr 2023 Terms of Use: https://www.spiedigitallibrary.org/terms-of-use 
Proc. of SPIE Vol. $8382838201-6$

Downloaded From: https://www.spiedigitallibrary.org/conference-proceedings-of-spie on 26 Apr 2023 Terms of Use: https://www.spiedigitallibrary.org/terms-of-use 


\title{
Conference Committee
}

\author{
Symposium Chair \\ Kevin P. Meiners, Office of the Secretary of Defense (United States) \\ Symposium Cochair
}

Kenneth R. Israel, Lockheed Martin Corporation (United States)

Conference Chairs

G. Charmaine Gilbreath, U.S. Naval Research Laboratory (United States)

Chadwick T. Hawley, National Signature Program (United States)

Program Committee

Kelly W. Bennett, U.S. Army Research Laboratory (United States)

Carlos O. Font, U.S. Naval Research Laboratory (United States)

Herbert J. Mitchell, U. S. Naval Postgraduate School (United States)

Joseph E. Peak, U.S. Naval Research Laboratory (United States)

Frank Pipitone, U.S. Naval Research Laboratory (United States)

Carl Salvaggio, Rochester Institute of Technology (United States)

Noriko Satake, University of California Davis Medical Center (United States)

\section{Session Chairs}

1 Active and Passive Signatures III

Charmaine Gilbreath, U.S. Naval Research Laboratory (United States)

2 Materials Detection Signatures

Kelly W. Bennett, U.S. Army Research Laboratory (United States)

3 Human Signatures

Carlos O. Font, U.S. Naval Research Laboratory (United States)

$4 \quad$ Spectral Signatures

Chadwick T. Hawley, National Signature Program (United States)

5 Mathematical Methods

Autumn Williams-Bess, Applied Systems Research, Inc., CACl (United States) 
6 Atmospheric and Tropospheric Signatures

Frank Pipitone, U.S. Naval Research Laboratory (United States)

Proc. of SPIE Vol. $8382838201-8$

Downloaded From: https://www.spiedigitallibrary.org/conference-proceedings-of-spie on 26 Apr 2023 Terms of Use: https://www.spiedigitallibrary.org/terms-of-use 